\title{
The Concepts Related to Islamic Education Modernisation
}

\author{
Zailani \\ University of Muhammadiyah Sumatera Utara \\ zailani@umsu.ac.id
}

\begin{abstract}
Islamic education is facing difficulties in making modernisation efforts. One of the reasons is that the process of modernisation begins with the Western in science and technology. The process of modernisation directly gives the effect of westernisation in Islamic education. The desire for renewal turns out to be the westernisation for Islamic education. Several meanings are mostly the same ideas in modernisation. They are modern, transformation, reformationation, revitalisation, revitalisation, actualisation, and contextualization. This paper will explain it and which concept is closer to modernisation. The goal is how the efforts of educational modernisation find the right way in seeking the Islamic educational rule back to the Islamic law. Exemplifies the Western in the development of science and its methodology but provides a filter, contextualises it into Islamic education while keeping the Qur'an and Sunnah as the primary basis for the modernisation of Islamic education.
\end{abstract}

Keywords: Concept, Modernisation, Islamic Education

\section{INTRODUCTION}

The growth and development of Islam are in line with Islamic education itself. Islamic education that cannot be separated in the development of the Islamic world. That is why the process of introducing Islam begins to the human race. Early Islamic education, ie, when revelation was revealed, the center of Islamic education was the Apostle. All matters related to Islamic law and its surroundings are always solvable. Besides, the Islamic education curriculum is simpler, based on the needs of the time.

Now the development of Islam has undergone many changes. The need is expected to change and adjust the pattern of Islamic education modernly. Historically, Islamic education experienced its heyday. The mind was very open to the emergence of scientists in the field. The rewards to the scientists were considerable. But after the fall of the Umayyads and Abbassyiah dynasties, Islam had not been able to rise in its true meaning. For now, the direction of knowledge does not rely on the Islamic rules, but the Western rules. The number of the center of study Ke-islaman in several renowned campus in the West signifies how the life of the scientific world there. Islamic education needs to see itself again and the environment that the world has undergone many significant changes. The issue now forms what changes are needed in answering those needs by using the theory of modernization, transformation, reformationation, revitalization, contextualization or westernization.

\section{METHOD}

The research method was qualitative method using the library research while the approach used was descriptive analytical which aimed to obtain information deeply. The analysis was done from the available information and took the conclusion.

\section{RESULT}

Modern is defined as the latest [1], cutting-edge or attitude and way of thinking, and how to act according to the demands of the times. Modernization of education in Indonesia is known as reformationist term. Reformationers are defined as manifestation of a change by looking at the situation and conditions of the future. The main purpose of modernization is to adjust the teachings of religion to the development of science [2].

Long before the Western people introduced the term of modernization into Islam, in fact that Islamic terminology already had the word tajdid as a synonym of modernization or renewal. In Arabic Dictionaries, the word Jaddada is defined in the context of Jaddada al-syai, which means making something new. Jadid is the opposite of khalaq and jaddah is the basic word of jadid which is the opposite of obsolete. From the above three words (modenization, renewal and tajdid), it can be formulated as follows: first, something which had been renewed previously existed clearly and was known by human; second, something had been eaten in such an age that was ancient. All three things were then returned to the original state: modern, actual and relevant. The person acted scientifically, which means he acted according to the prevailing laws of nature. Therefore, he did not oppose the laws of nature, instead using the laws of nature itself, so he obtained a high effectiveness. While tranformation was defined by the transfiguration (form of nature, function).

Transformation is also interpreted by change of form[3]. Substitution here is not interpreted the first form[4], nature or wrong function, but it continues process, 
resulting in the process of change towards the newer. An example is the State Islamic University of North Sumatra. Previously, the name was IAIN SU (State Islamic Institute of North Sumatra). It took ten years to change the name of State Islamic Institute of North Sumatra to State Islamic University of North Sumatra. It needed some steps to be a university. The transformation was about changing the form and name. Reformation itself is British word, which means reformations of reformation, renewal movement or a drastic change for improvement (social, political or religious).

The implicit meaning of the word reformation is the change of form to be better, in accordance with the concept of being inherited. But on the way of the system, there is a mistake that system is no longer in accordance with the initial khittah. The run is off the mark and many errors require correcting. Herein lies the role of reformationation to restore into its initial form based on the established standard rules. Reformationation usually has a great risk because sudden reformations are triggered by certain events that require total change. One of the cases that is still in case is the Indonesian reformationation in 1998. The massive people demonstrated to insist the change of democratic system at that time. It caused the fall of Soeharto's presidensial regime. It is known as the reformation era now.

Things have changed, starting from amendments to laws, government structures and others. So reformation means rapid change of form. In the world of reformation, education is not as grotesque as imagined in government politics. For example, after the Ministerial Decree 1975 about the change of curriculum on Islamic education, madrasah became part of the national education in which madrasah previously was limited to the guidance and supervision of the Minister of Religious Affairs [5]. Post Regulation SKB3 Minister reformation occured in some fundamental aspects. First, the recognition of madrasah as an integral part of national education. The change of madrasah after the Ministerial Decree was a reformation. There is a revamped form.

Revitalization means the act of reviving or revitalizing. As well as reformation, it reinvigorates old thing to be preserved. Actualization is taken from the root of an actual word which means happening [6], being the talk of the crowd, just happened or something new. The actual word also means how things are adjusted by now, things that are up-to-date.

In general, Muslims need to do renewal (modernization). Since the presence of contemporary times is not the same as the beginning of the Islamic presence, the need of renewal is needed to address today's challenges and current globalization. Religion must be present in the midst of the hustle and bustle of human's activity because religion serves as a social control and motivator of human dimension development [7]. Then, it takes the spirit of tajdid to rediscover the spirit and substance of religious teaching.

The most phenomenal historical fact, which shows the existence of modernization and innovation in various aspects is the progress achieved by Islamic education in old times. From the halaqah system with the material focusing on the religious sciences in the madrasah system that developed in the 8th century to the 14th century, Muslims reached the pinnacle of world civilization and were unmatched by other nations in the world, including West.

Not all matters related to Islam are in modernization, Hasan Asari conveyed certain things from Al-Qur'an and Hadith Mutawatir the qath'iy al-dalalah (fixed intent). This teaching is not the goal of renewal. Renewal in Islam is relative, or dhanni of the teachings of Islam.

The modernization of education is an approach to a long-term solution of today problems for the future. Therefore, the modernization of education is important in the birth of a modern Islamic civilization.

In the form of educational institutions during the Apostle's era, the main institution of education was the mosque. Now the main institutions of Islamic education are schools, such as pondok pesantren, madrasah and many more. The mosque is still used as an Islamic educational institution, but its role goes into non-formal territory, not the main cluster of reformationation [8], This word implies the wrong thing to be reformed. It answers to improve the previous system [8].

Nowadays, reformation is needed for it is not just the loss of the intellectualism spirit as the previous generations pointed out. The emergence of old-fashioned understanding, loss of awareness, and understanding of Sharia (fiqh) are more superior than others. So, that legitimizing and justifying are wrong. This has a dominant influence in the emergence of a dichotomy or dualism of science. One says the science of religion and others say common science. The first part of the group, the religion science deserves to be taught than other sciences while general science is more needed globally. In fact, both types of grouping in the level of Islamic philosophy are wrong. Since knowledge is all from God and have the same goals, this stigma is very irrelevant and needs reformation. This is an example of the Dark Age implications that occurred in the middle ages around the 1250-1800 AD.

Revitalization means reviving the previous one. The resurrection here is on the good aspect of the Golden Age. What rises here is one of the high intellectual spirits. Life is the atmosphere of research and intellectual exploration to be open to the outside world and prioritizing research and review rather than judgment. In old times, the activities of translators were part of the initial process for long-term goals.

Revitalization means extracting the main source of the Qur'an and As-Sunnah as a barometer to reactivate a religious spirit. The basis of Islamic Education is the Qur'an and Hadith. Syaibani added Ijtihad to the scholars. 
After the death of the Prophet, the seeds of Islamic Progress bebar-true sowing to experience the peak of progress began since the end of the Old Period in 750 until 1250 AD. [9]

Things taken here are the concept and spirit, as the historical nature is different. Something outdated is still worn but its different intencity for revitalization does not mean to evoke habits of the history. Like educational institutions in the Old Period, the mosque is as the center with sophisticated and modern architecture. The mosque remains one of the educational institutions, but the portion has been reduced considerably and no longer part of formal education.

The meaning of revitalization here returns to the real Islam. They are the Qur'an and the Sunnah. This is the original teaching of Islam, while others are the ulama's perseverance to help produce interpretations of the Qur'an and the Sunnah. The nature of human formulation is not separated from the socio-culture, and the spirit taken here are the activities to rehold the division and the two sources using the present mirror.

The above concepts are not the same as the principle and the concept of westernization because the concepts are more to see the West in the full sense, to be imitated in all aspects of education. This certain doctrination in Islam is contradictory because it emerges secularism that will lose the identity of Islamic education. Islamic education is not the same as Western education, especially regarding matters related to the principles and guidance of life. Western epistemology challenges the spiritual dimension while Islamic epistemology stems from the Qur'an and AsSunnah, which aims to provide space for Muslims.

In the context of the philosophy of Islamic education, the goal of Islamic education is based on the God as an integral part that cannot be separated from Islamic education. Islamic education is not free-value. The value is the morality that comes from the Qur'an and As-Sunnah because morality is an obligation of Islamic education to produce skilled labor. It is charged to the curriculum. Hence, the curriculum should accommodate the needs of psychomotor and affection in this case related to morals and manners [10].

This is one of the hallmarks of why westernization is a forbidden matter in Islamic education. But it does not mean that things which come from the West are marginalized. It is necessary to enact the verification of matters that become the parts of the modernization of education which can be implemented in Islamic education. One of them is the richness of his field of science that the study of science and technology is more advanced than the Islamic region, as well as the methodology. This is inversely proportional to Islamic education, but weak in natural sciences and technology. That is why researchers and inventors are mostly from Western. For such things, it is worth to be adopted by Islamic education as a means to raise a nation's character.
Westernization can change the attitude patterns of graduate outcomes intellectually to compete with other groups, but it loses the basic identity of the goal of Islamic education. That condition could happen because the modification of Islamic education in Muslim areas happens on the background of the intensity of interaction between Muslims and Western people.

Since the purpose of renewal is getting better, the process of renewal is done carefully and departed to a common need. Analyzing all aspects and seeing the weakness and strength depart from the same source that is Al-qur'an and As-sunnah. We must keep these two guidelines as a barometer of stepping and making changes, especially in Islamic education.

Several terms are used, like modernization, revitalization, actualization, contextualization, transformation, reformation and westernization. Syahrin tends to emphasize the concept of modernization. According to him, other words contain bias. Munawir Syazali launched the idea of actualization and contextualization, which is in agreement with Amin Abdullah, but the value of more than the modern word is broader and has several definitions. Speakers argue that the above terms have the same meaning in making the renewal, but in scope, the word modernization is more representative than other concepts.

Aspects covered by the term of modernization are more comprehensive and contain a positive meaning, not only the modernization of educational institutions, but also the whole Islamic education system. Reformations containing modernization are widely used in literature opposed to traditional. Azra himself mentioned the renewal in Islamic education as modernization. He said that the modernization program of Islamic education has its roots in the notion of "modernism" and Islamic institutions as a whole[11].

In other words, the modernism of Islamic education cannot be separated from the revival of the idea of the Islamic modernism program. When there is a renewal explosion, the space or dimension that implicates the implication is education. Because the position of Islamic Education is very urgent to form a civilized and advanced Islamic society, the renewal in the field of education necessity is done as part of answering the will of the times and the needs of Islamic education itself. Here, there will come other ideas of thinking about Islam. In other words, Islamic Education spears forward and retreats Muslims. Azra also mentioned that education in modern societies or modern-day societies essentially serves to provide a link between learners and the socio-cultural environment which is constantly changing. In many ways, education is consciously used as an instrument to change political and economic systems. 


\section{CONCLUSION}

Based on the need, Islamic education must adapt the times environment. But it still cannot be separated from the roots of history and Islamic doctrine because it comes from the Qur'an and Sunnah. The glory of Muslims is not only in the form of historical nostalgia to glorify the Golden Age in the past, but also it escaped the self-pursuit of catching up with other nations. So, any theories and concepts used, in fact are only how Islamic education presents itself as an integral part of Muslims. It comes in the form of solving humanitarian problems, both in practical and theoretical level. The theory of modernization, transformation, reformation, revitalization, actualization, and contextualization have the same spirit although in different terms. In the context of Islamic education, this theory is positive and fresh. To refresh Islamic education is better to answer the needs of the people. It is not denied that the process of renewing Islamic education is facing not only considerable problems, but also a challenge within the internal Islam itself. Western civilization has experienced a considerable surge, especially in science and technology. So, the eyes of the world go to see the West as a barometer of progress. A certain level happening is not the process of renewal of Islamic education, but the westernization of Islamic education. This situation can substantially affect the paradigm of thinking and direction of educational goals. In this context, the process of westernisation is not in line with educational reformation because westernization is aspects of palagiasm. It does not only conform to the path and philosophy of Islamic education, but also violate norms that are doctrinal from the teachings of Islam. So, the ideas of education renewal do not present an empty space. He has experienced the process of introduction and touch with the condition of contemporary and civilization of other nations.

\section{REFERENCES}

[1] S. Nizar, Seabad Buya Hamka Discussing Intellectual Dynamics and Thought About Islamic Education. Jakarta: Kencana, 2008.

[2] Shahminan, "Modernization of Islamic Education System in Indonesia in the 21st Century.," Sci. J. Peuradeun, vol. II, 2014.
[3] D. Pendidikan, kamus Besar Bahasa Indonesia. Jakarta: Pustaka Utama, 2008.

[4] J. M. E. Hasan Shadily, , Kamus Inggris Indonesia (Jakarta: Gramedia,2005), $\quad$ h. 601. Jakarta: Gramedia, 2005.

[5] A. Nurhayati, "Fenomena Madrasah Pasca SKB 3 Menteri Tahun 1975 dan Implikasinya terhadap Dunia pendidikan Islam," Ta'allum, vol. 01, p. 133, 2013.

[6] Y. Ilyas, "Reaktualisasi Ajaran Islam: Study Atas Pemikiran Munawir Sjadzali," Al-Jamiah, vol. 44, p. 230, 2006.

[7] N. Umar, Islam Fungsional; Revitalisasi dan Reaktualisasi Nilai-Nilai KeIslaman. Jakarta: Gramedia, 2014.

[8] Aulia Reza Bastian, Educational Reformation; Steps of Renewal and Empowerment of Education In the framework of Decentralization of Indonesian Education System. Yogyakarta: Lappera, 2002.

[9] H. M. Baidhawi, "Modernisasi Pendidikan Islam (Telaah Atas Pembaharuan Pendidikan \& Pesantren)," Tadris, vol. 1, 2006.

[10] A. R. Assegaf, The Flow of Islamic Education Thought; Hadharah the knowledge of old characters Until The Modern. Jakarta: Raja Grafindo Persada, 2013.

[11] A. Azra, . Pendidikan Islam;Tradisi Dan Modrenisasi di Tengah Tantangan Milenium III. Jakarta: Kencana, 2012. Jakarta: Kencana, 2012. 